押野 悟 ${ }^{1}$ ，齋藤 洋一2)，木下 学 ${ }^{1)}$ ，貴島 晴彦1)

1) 大阪大学大学院医学系研究科脳神経外科学, 2) 同 脳神経機能再生学

\title{
Medical Treatment and Surgical Indications for Functioning Pituitary Adenomas
}

\author{
Satoru Oshino, M.D., Ph.D. ${ }^{1}$, Youichi Saitoh, M.D., Ph.D. ${ }^{2}$, Manabu Kinoshita, M.D., Ph.D. ${ }^{1)}$, and \\ Haruhiko Kishima, M.D., Ph.D. ${ }^{1)}$ \\ 1) Department of Neurosurgery, Osaka University Graduate School of Medicine, 2) Department of Neuromodulation and \\ Neurosurgery, Osaka University Graduate School of Medicine
}

Functioning pituitary adenomas cause various clinical manifestations due to excess hormones secreted by the tumor. The prevalence is, in order, prolactinoma, acromegaly, and Cushing disease. Surgical treatment is the treatment of choice, except for prolactinoma, while medical therapy is for the patients without endocrinological remission after surgery. Dopamine agonists and somatostatin analogs are the major tumor-target medications, as those receptors are expressed on the majority of the adenoma cells. Also, end-organ-target medications are used as adjuvant therapy for biochemical control.

Prolactinoma is the most common subtype of functioning pituitary adenomas. Some pitfalls exist in the diagnosis, including non-tumor causes of hyperprolactinemia, macroprolactinemia, hook effect, and possibility of plurihormonal adenoma. Medical treatment with dopamine agonists can achieve tumor shrinkage and hormonal control in a majority of patients. The goal of treatment in prolactinoma is different, depending on the patient's age, sex, and situation. Surgical treatment might be considered positively for macroadenoma in young women in whom strict hormonal control will be required.

Dopamine agonists, first and second generation of somatostatin analogs, and GH receptors antagonist are used as medical therapy for acromegaly. Through combinations of those medications as well as recent advancements in surgery, the control rate of IGF-1 has been improved. More "certainty" and "safety" will be required for surgical treatment of acromagely.

Same as acromegaly, surgical treatment is the first choice for Cushing disease. Dopamine agonists and second generation somatostatin analogs as tumor-target medications, and inhibitors of adrenal steroidogenesis or antagonists of glucocorticoid receptors as adjuvant end-organ targets are used as medical treatment. However, the disease control rate is not satisfactory. The presence of MRI-invisible adenoma is an unsolved problem and new imaging modalities are expected.

Some new medical therapies are in development(undergoing clinical trials), including from moleculartarget drugs for tumor control to end-organ targeted selective estrogen receptor modulators as adjuvant therapy. Although those medical treatments will progress, surgery is the ideal modality and mainstay of treatment. The future direction will be to maximally remove the tumor and select an effective adjuvant therapy based on the characteristics of the receptor and gene expression.

(Received September 25, 2020; accepted October 19, 2020)

Key words : functioning pituitary adenoma, prolactinoma, acromegaly, Cushing's disease Jpn J Neurosurg（Tokyo） 30: 19-28, 2021

連絡先：押野 悟, $\overline{\mathbf{T}}$ 565-0871 吹田市山田丘 2-2 大阪大学大学院医学系研究科脳神経外科学

Address reprint requests to: Satoru Oshino, M.D., Ph.D., Department of Neurosurgery, Osaka University Graduate School of Medicine, 2-2 Yamadaoka, Suita-shi, Osaka 565-0871, Japan 


\section{はじめに}

機能性下垂体腺腫は腫瘍細胞から分泌される過剩なホ ルモンによりさまざまな症状を呈する疾患である。本稿 ではそれらのうち頻度の高いプロラクチノーマと先端巨 大症，クッシング病の薬物治療と外科治療の現状につい て概説する。特に脳神経外科医が単独で薬物治療まで担 うことが多いプロラクチノーマについては，診断の注意 点なども記載した。 なお，本稿では扱わなかったが，放 射線治療も大変重要なオプションであり, 機能性下垂体 腺腫に対する集学的治療として広く用いられている.

\section{機能性下垂体腺腫の新分類と薬物治療}

これまで機能性下垂体腺腫は分泌されるホルモンに よって分類されてきたが，2017 年に WHO から転写因子 に基づき，腫瘍の起源となる細胞系統で分類することが 提唱された ${ }^{30)}$ 。その新分類について表（Table 1）と下記 に簡単にまとめる25)29)37。 まず PRL, GH, TSH を分泌す る細胞はおのおの lactotroph, somatotroph, thyrotroph と 呼ばれるが，系統としては同じ Pit-1 陽性細胞となる。 ACTH を分泌する corticotroph は T-Pit 陽性, FSH や LH を分泌する gonadotroph は SF-1 陽性の細胞系統に分類さ れる. Pit- 1 系の大部分がホルモン過剩症状を呈するの に対し, SF-1系は多くがホルモン過剩症状のない非機 能性下垂体腺腫の臨床像となることが多い。そして TPit 系には症候性 (クッシング病) と無症候のものが混在 する.さらにこの分類では増殖能が高く aggressive な性 質をもつ 5 タイプとして male lactotroph adenoma, sparsely granulated adenoma, Crooke's cell adenoma, silent corticotroph adenoma, plurihormonal Pit-1-positive adenoma が加えられた (Table 1)。後述するが男性はプロ ラクチノーマにおける薬剤抵抗性の一因子である ${ }^{41)}$.

Sparsely granulated somatotroph adenoma は分泌顆粒がま ばらにしかない $\mathrm{GH}$ 産生腫瘍で, 腫瘍細胞の $70 \%$ 以上に fibrous body がみられる。分泌顆粒が密にある densely granulated somatotroph adenoma と比べて, 大型で薬物反 応性に乏しいことが多い. ACTH 産生腫瘍ではクッシン グ徵候を呈さない silent corticotroph adenoma や，Crook 変性，つまり細胞内にサイトケラチン線維（硝子化）が 蓄積した Crooke’s cell adenoma が aggressive な性質を有 するとして挙げられている ${ }^{41)}$. Plurihormonal Pit-1-positive adenoma は，従来 silent subtype III pituitary adenoma と呼ばれていたもので，その名のと扮り $\mathrm{Pit}^{-1}$ 陽性で複 数のホルモンを有している腫瘍細胞からなる。ホルモン 過剩症状を呈さない例が多く，若年発症で大型浸潤性の ことが多い ${ }^{30)}$ 。転写因子に基づく方向，つまり特定のホ ルモンを分泌する細胞に分化しなかったものが，より腫 瘍としての性質を強く呈するのかもしれない。これらの タイプは経過が必ずしも良好ではないため，下垂体腫瘍 を良性の意味が強い腺腫（adenoma）ではなく，下垂体 神経内分泌腫瘍 (pituitary neuroendocrine tumor：PitNET）と呼ぶように提唱されている ${ }^{30} 37$ )。 今後はこの新 分類に基づく知見が蓄積し，後述する薬物治療にも応用 されると期待されるが，本稿では現時点で一般的と思わ れる従来の分類や表現を用いる。

下垂体前葉ホルモンには，それ自体の作用と副腎皮質 や甲状腺など下流器官を介した作用がある。下垂体前葉

Table 1 WHO (2017) classification of pituitary adenoma (pituitary neuroendocrine tumor) (from Ref. 26, 30, 37)

\begin{tabular}{|c|c|c|c|c|c|}
\hline $\begin{array}{l}\text { Producing } \\
\text { hormone }\end{array}$ & Clinical diagnosis & Prevalence (\%) & Cellular linage & $\begin{array}{l}\text { Transcrip- } \\
\text { tion factors } \\
\end{array}$ & Specific type (aggressive) \\
\hline $\begin{array}{l}\text { PRL } \\
\text { GH } \\
\text { ACTH }\end{array}$ & $\begin{array}{l}\text { Prolactinoma } \\
\text { Acromegaly } \\
\text { Cushing disease }\end{array}$ & $\begin{array}{l}32-66 \\
8-16 \\
2-6\end{array}$ & $\begin{array}{l}\text { Lactotroph } \\
\text { Somatotroph } \\
\text { Corticotroph }\end{array}$ & $\begin{array}{l}\text { Pit-1 } \\
\text { Pit-1 } \\
\text { T-pit }\end{array}$ & $\begin{array}{l}\text { Male lactotroph } \\
\text { Sparsely granulated } \\
\text { Silent corticotroph, } \\
\text { Crooke's cell }\end{array}$ \\
\hline TSH & $\begin{array}{l}\text { TSH producing } \\
\text { adeoma }\end{array}$ & $<1$ & Thyrotroph & Pit-1 & \\
\hline FSH $(>\mathrm{LH})$ & $\fallingdotseq \mathrm{NFPA}$ & $28-54$ & Gonadotroph & $\mathrm{SF}-1$ & \\
\hline $\begin{array}{l}\text { None } \\
\text { Multiple }\end{array}$ & NFPA & $\begin{array}{l}\text { Rare } \\
\text { Rare }\end{array}$ & Null cell & $\begin{array}{l}\text { None } \\
\text { Multiple }\end{array}$ & $\begin{array}{l}\text { Plurihormonal Pit-1 posi- } \\
\text { tive }\end{array}$ \\
\hline
\end{tabular}

PRL: prolactine, GH: growth hormone, ACTH: adrenocorticotrophine stimulating hormone, TSH: thyroid stimulating hormone, FSH: follicle stimulating hormone, LH: luteinizing hormone, NFPA: non-functioning pituitary adenoma 
からのホルモン分泌は視床下部により制御されるが，抑 制系の主軸はドパミンとソマトスタチンで, 前者は PRL の, 後者は GH と TSH の分泌を抑制する。この作用を利 用したのがドパミン作動薬とソマトスタチン製剤でおの おの PRL，GH，TSH 産生腫瘍の治療に用いられる。 た，これらの薬物が作用するドパミン D2 受容体やソマ トスタチン受容体は, 種々の下垂体腺腫細胞に発現して いるため， 2 剂とも機能性だけでなく非機能性下垂体腺 腫の治療にも用いられている . 薬物治療としては, ド パミン作動薬やソマトスタチン製剤のように腫瘍そのも のを抑制するものと, 下流器官でのホルモン産生やその 作用を抑制するもの，不足したホルモンを補充するもの が考えられる。

\section{プロラクチノーマについて}

\section{1 プロラクチノーマの診断}

プロラクチノーマは機能性下垂体腺腫の中で最も頻度 が高く, 50 歳までは女性に多いが 50 歳以降では男女差 がないとされる ${ }^{40)}$. 女性では月経異常が診断の契機とな るが，最近は男性の不妊や更年期障害から診断される例 もしばしば経験する。プロラクチノーマの診断では MRI の読影が重要なこともあり, 脳神経外科に直接紹介され ることが多いと思われるが, 診断が難しい例も少なくな い.ここではプロラクチノーマの診断における注意点を 4つ紹介する。

まず，プロラクチノーマ以外の高 PRL 血症の要因につ いてである。一般的に PRLが $250 \mathrm{ng} / \mathrm{ml}$ 以上だと腺腫の 可能性が高いが, $100 \mathrm{ng} / \mathrm{ml}$ 以下の場合は他の要因を考 えるべきで41), 最も頻度が高い薬剤性から疑い, ドパミ ン遮断作用のある抗精神病薬や抗うつ剂などの服用歴を 確認する ${ }^{6)}$. 次に原発性甲状腺機能低下や腎機能障害を 除外する。また PRL 值は GH P ACTH ほどではないが 生理的に変動することがあり，再検したら正常值という 例も経験する. 正常化しなくても PRL值が大きく変動す る例も腺腫以外の要因が多いので注意したい. 大型の非 機能性下垂体腺腫やラトケ囊胞などでも下垂体茎の障害 で高 PRL 血症になるが，腫瘍の大きさに対して PRL 值 が低いことで判断できる，ただし囊胞性の腺腫や下垂体 卒中例では判断が難しい場合がある. PRLが $100 \mathrm{ng} / \mathrm{ml}$ 前後で, MRIでごく小さな病変のみが疑われる例での判 断は難しいが，プロラクチノーマと診断して薬物治療を 開始した場合は PRL 值の低下とともに腫瘍と判断した 病変が縮小するかを必ず確認する。どのような要因でも ドパミン作動薬により PRL值は低下することが多く，そ
のまま治療が継続されると診断に戻れなくなるので, 迷った場合は内分泌内科にも相談し，慎重に診断すべき である。

2つ目はマクロプロラクチン血症である。マクロプロ ラクチンとはPRL とその自己抗体 $(\mathrm{IgG})$ との複合体で, それ自体には生理活性がないため, 無症状の高 PRL 血症 となる。決してまれな現象ではなく, 高 PRL 血症の要因 の $19 \%$ を占的 ${ }^{41)}$, 日本の医療機関職員 1,330 人（女性 1,010 人)を対象にした調査では全体の $3.68 \%$ にマクプ ロラクチンが検出されたという16)。ポリエチレングリ コールで処理すると除去できるので，疑わしい場合は臨 床検査技師に相談するとよい.

3つ目はHook 効果である。これは，いわゆるサンド イッチ法，つまり固定抗体で抗原を捉え，それに標識抗 体を吸着させる検査法で，抗原が過剩な場合に生じ得る ものである．多すぎて固定抗体に吸着しなかった抗原に 標識抗体が付着し流されてしまうため，見かけ上低值に なってしまう。V Vilar $ら^{41}$ は分葉型の巨大腺腫で，本来 21,200 ng/mlの PRL 值が $92 \mathrm{ng} / \mathrm{ml}$ だった例を報告してい る. 非機能性下垂体腺腫かプロラクチノーマかで治療方 針がまったく異なるので，注意したい現象である．Hook 効果が疑われた場合は，サンプルを希釈することで正確 な值が得られる。

4 つ目はホルモン同時産生腫瘍の可能性である. PRL と $\mathrm{GH}$ の組み合わせの頻度が高いが, それらは $\mathrm{GH}$ 值が 低く先端巨大症の徴候に乏しいことも多いので注意した $い^{42)}$. 診断時には必ず IGF-1 を含めた下垂体ホルモン一 式を計測し，同時産生腫瘍ではないか確認する.

\section{2 プロラクチノーマに対する薬物治療}

プロラクチノーマに対してはドパミン作動薬による薬 物治療が第一選択である ${ }^{28)}$. 日本ではカベルゴリン，ブ ロモクリプチン, テルグリドが使用されるが, $\mathrm{D} 2$ 受容体 への親和性がより高く，ホルモン抑制と腫瘍縮小効果に 高いカベルゴリンが推奨されている ${ }^{6) 28)}$. カベルゴリン は半減期が長いため週 1 2 回の内服でよく, 他の 2 剂と 比べ嘔気などの副作用も少ない. ドパミン作動薬は妊娠 が判明したらすぐに中止するが，直近に妊娠を計画して いる場合はあえて作用時間の短いブロモクリプチンやテ ルグリドを使用する考えもある41).

ドパミン作動薬の副作用として嘔気や眠気，精神症状 がある、それに加え，麦角系アルカロイドのカベルゴリ ンではパーキンソン病に対する長期投与での心臟弁膜症 が報告されている43)。ただし，プロラクチノーマに対す る投与量（1２ mg/週）での危険性は少なく, 50 歳以上 
で $3 \mathrm{mg} /$ 週を 5 年以上継続した場合に定期的な心エコー が推奨されている

ドパミン作動薬を投与すると腫瘍は劇的に縮小する が，頭蓋底浸潤例では髄液漏に注意する。投与前に必ず CT や MRI で頭蓋底や硬膜の状態を確認する。また妊娠 中はドパミン作動薬の中止に加え, エストロゲンが生理 的に増加するため腫瘍が増大することがある. Molitch ${ }^{26)}$ の reviewによると, 妊娠中に腫瘍が増大する割合はミク 口腺腫で $2.1 \%$, 手術や放射線治療後で $4.7 \%$ と低かった が, 薬物治療のみで妊娠に至つた例では $21 \%$ と比較的高 かった。薬物治療前の腫瘍が大きかった場合や囊胞性病 変例では，注意して観察しなければならない。

カベルゴリンでの内分泌寛解率は $90 \%$ とされるが, 抵 抗性のプロラクチノーマもあり, 男性例, 大型で浸潤性 の腫瘍, MEN-1や AIP といった遺伝子異常, 若年発症, 囊胞性などが因子とされる ${ }^{41)}$ 。その場合, 手術や放射線 治療が検討されるが, 年齢や性別によっては高 PRL 血症 を是正する必要がない場合もある ${ }^{2)}$. 個人的には閉経後 の女性や男性の多くでは, 腫瘍サイズの制御を治療目標 としている. PRL值が正常化するのに越したことはない が, 仮に高值でも無症状であるなら, その状態を維持で きればよいという考えである。もちろん男性例でも性腺 機能を重視する場合は, PRLの制御を治療目標とすべき である。また閉経前の女性で PRL值がどうしても制御さ れない場合は, 骨塩低下の予防や子宮粘膜のサイクル維 持を目的に抑制された性ホルモンのみ補充することもあ る. 患者の状況によって治療目標は異なるので, よく検 討し柔軟に対応すべきである.

ドパミン作動薬以外の薬物治療としては, 他の機能性 下垂体腺腫と同様にソマトスタチン製剤や tamoxifen な どの選択的エストロゲン受容体調整薬が試されてい る3239)。また AMP 活性化キナーゼの作用を増強する metformin や, mTOR 阻害薬の everolimus などの報告が あり, epidermal growth factor 系をブロックする tyrosine kinase inhibitor の lapatinib が臨床試験中である ${ }^{32) 39)}$.

\section{3 プロラクチノーマに対する外科治療}

プロラクチノーマに対する一般的な手術適応は, 薬物 抵抗性や不耐例 ${ }^{28)}$, 下垂体卒中や囊胞で mass effect を有 する場合だが, 一部のガイドラインでは,「手術で完治が 見込まれ，患者が希望した場合」が追記されている24). プロラクチノーマの治療目標は患者の状況によって異な るが，一般的に長期間 PRL 值を制御する必要があるのは 若年女性例である。実際 2011 年以降の当施設でのプロ ラクチノーマの手術例は若年女性が $80 \%$ 以上を占めて
いた。 35 歳以下の 31 例（平均 25 歳）では術前 PRL 值 が 290.7 (89 1,730) $\mathrm{ng} / \mathrm{ml}$ で, マクロ腺腫, 下垂体卒 中, 薬剤抵抗例が主体だった。術後 5.3 年で 22 例 (71\%) が治癒， 8 例が少量（0.5 mg/週以下）のカベルゴリンで 正常化，1例は月経不順で未投薬の状態で，97\%で寛解 状態が維持されていた。 プロラクチノーマに対しては薬 物か手術の二者択一で, 手術を選択した場合は単独で完 治せねばならないと考元られがちである。しかし, 術後 に再燃しても少量の薬物で制御できることや妊娠中の再 増大などを考慮すると, 若年女性で PRL 值の高いマク口 腺腫例に対しては，総合的に手術の意義があると思われ る.

\section{先端巨大症とクッシング病}

プロラクチノーマ以外の機能性下垂体腺腫, つまり先 端巨大症, クッシング病, TSH 産生腫瘍に対しては, 外 科治療が第一選択となる ${ }^{28)}$ 。そして, 薬物治療は術後の 非寛解例に適用されるが，先端巨大症とクッシング病と ではその状況が異なる。

\section{1 先端巨大症に対する外科治療の現状}

最近の review では先端巨大症に対する術後寬解率は 35 65\% 程度で，全摘出できない例が一定数存在す る ${ }^{21)}$ 。しかし, 非寛解例でも腫瘍の摘出度は増し, 薬剤 や放射線治療，合併症の管理により病勢が制御されてい る例が多いように感じる。実際, 先端巨大症の標準化死 亡比は 2008 年の前後 10 年で 1.76 から 1.35 に減少し, 報告によっては一般群と差がないものもある11. 死因も 先端巨大症の特徵であった心疾患から悪性腫瘍に変化 し, やはり一般群と差がなくなりつつあるという ${ }^{17)}$ 。こ れら海外からの報告と日本での状況が同じかは不明だ が，これらの傾向を踏まえると，今後の外科治療には安 全性と確実性がより求められると考えられる。つまり, 全摘出できるはずの例では確実に寛解に持ち込むこと, 全摘出が難しい例では神経症状を呈する部位を中心に, 最大限かつ安全に摘出し薬物治療につなげることが重要 と思われる。代表例として，注意しないと取り残す恐れ があった症例と, 海綿静脈洞内の残存腫瘍だが内䅡動脈 の内後方だったので安全に摘出できた例を提示する (Fig 1, 2).

\section{2 先端巨大症に対する薬物治療}

現在, 先端巨大症に使用される薬剤はドパミン作動薬 とソマトスタチン製剤，GH 受容体拮抗薬である（Table 
Fig. 1 Representative cases with acromegaly

Case 1: $\mathbf{A}$ : The tumor extended from the sellar floor to the top of the left cavernous sinus wall along to the abnormal venous complex, which was detected as flow void (arrowhead) on the gadolinium-enhanced T1-weighted MR image.

B: The tumor and its pseudo-capsule were carefully dissected from the venous complex (arrowhead).

Case 2: An enhanced thin membrane (arrowhead) was detected in the lower part of the tumor on gadolinium-enhanced T1-weighted image (C). During surgery, we found a hole in the dura of the sellar floor. A small sinus was formed, and the tumor extended into it. The sinus was opened, and the tumor was totally removed (D).

Case 3: The surgery was carried out on a patient with a residual tumor in the right cavernous sinus (E) because it is located medial to the internal carotid artery (asterisk) in the posterior part of the cavernous sinus. The tumor was removed safely $(\mathbf{F})$, and endcrinological remission was obtained.
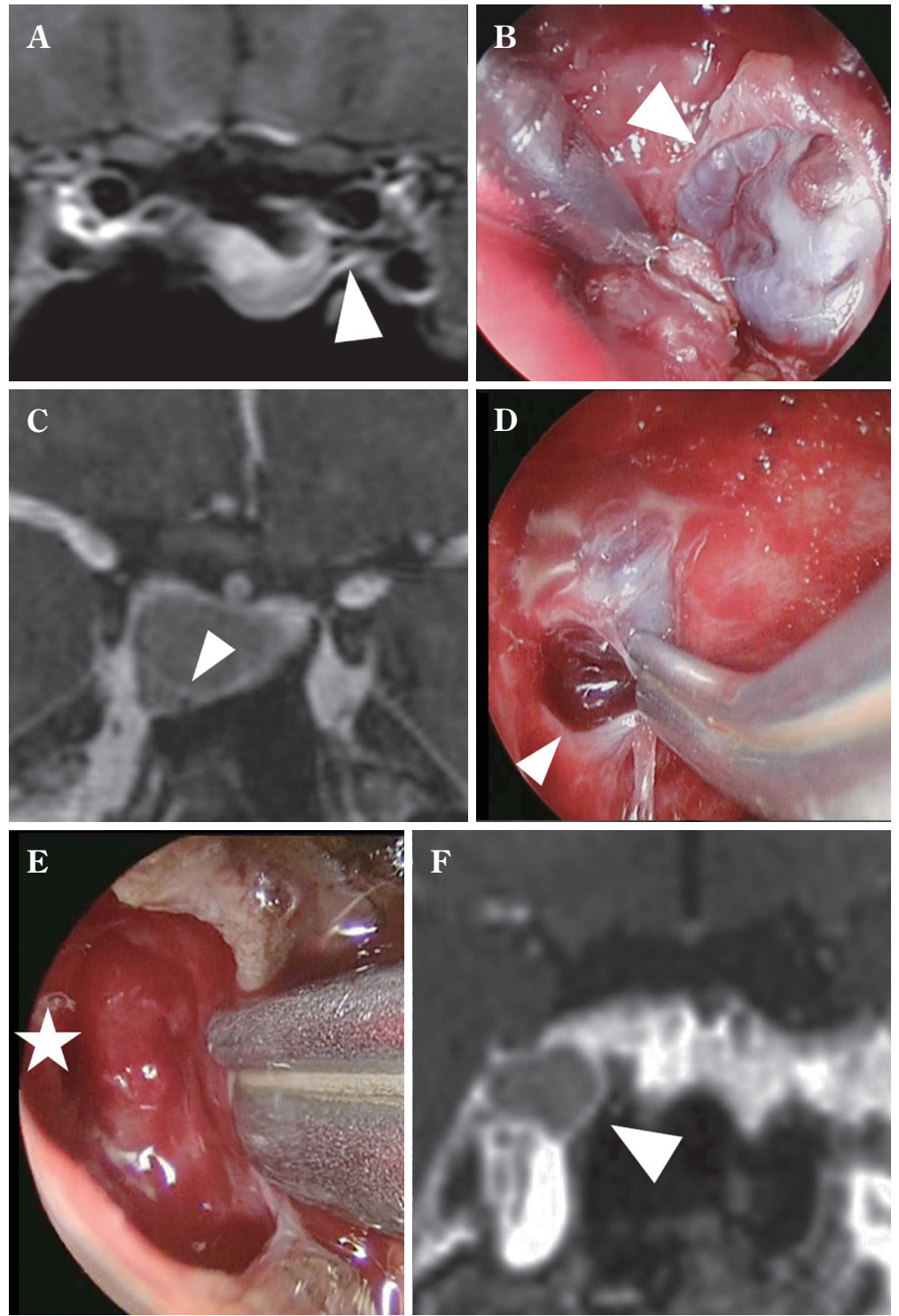

2). ドパミン作動薬としてはカベルゴリンが推奨されて

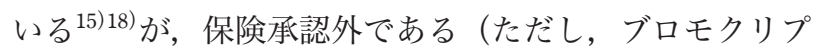
チンは承認されている)。ガルゴリン単剤での内分泌 学的制御率は 35〜 40\%で21), IGF-1 がやや増加（正常值 の 2.5 倍以下）した例での単剤投与やソマトスタチン製 剤への追加投与が推奨されている23).

現時点での薬物治療の主軸はソマトスタチン製剤で, $\mathrm{GH}$ の分泌抑制と腫瘍縮小効果を有する。受容体のサブ タイプ $2(\mathrm{SSR}-2)$ への親和性が高い第一世代のオクト レオチド (octreotide) とランレオチド (lanreotide) で は, 内分泌学的制御（IGF-1 が正常化かつ $\mathrm{GH}<2.5 \mathrm{ng} /$ $\mathrm{ml}$ ）は 30〜 40\%で得られ，20\%以上の腫瘍縮小が $67 \%$ の例にみられる ${ }^{21)}$. SSR-2 と 5 に親和性のあるパシレオ チド (pasireotide) が第二世代のソマトスタチン製剤で,
第一世代が無効だった例にも効果がみられる7)、いずれ の世代にも徐放剂があり，月 1 回の投与が基本となる. ソマトスタチンは膵臓や消化管からも分泌されるホルモ ンで，インスリン分泌や消化管の活動を抑制する作用が ある、そのため，ソマトスタチン製剤の副作用には下痢 などの消化管症状や胆石の形成，血糖值の上昇がある. 特にパシレオチドでは約 $70 \%$ で耐糖能が悪化するため, 糖尿病合併例では要注意である。

ソマトスタチン製剤とドパミン作動薬が腫瘍からの $\mathrm{GH}$ 分泌を抑制するのに対し，分泌された $\mathrm{GH}$ の作用を 阻止するのが GH 受容体拮抗薬のペグビソマント (pegvisomant）で，肝臓での IGF-1 合成が抑制され，筋肉や骨 への GH の直接作用も抑えられる。ガイドラインでは 2nd line として, ソマトスタチン製剤で制御できなかっ 

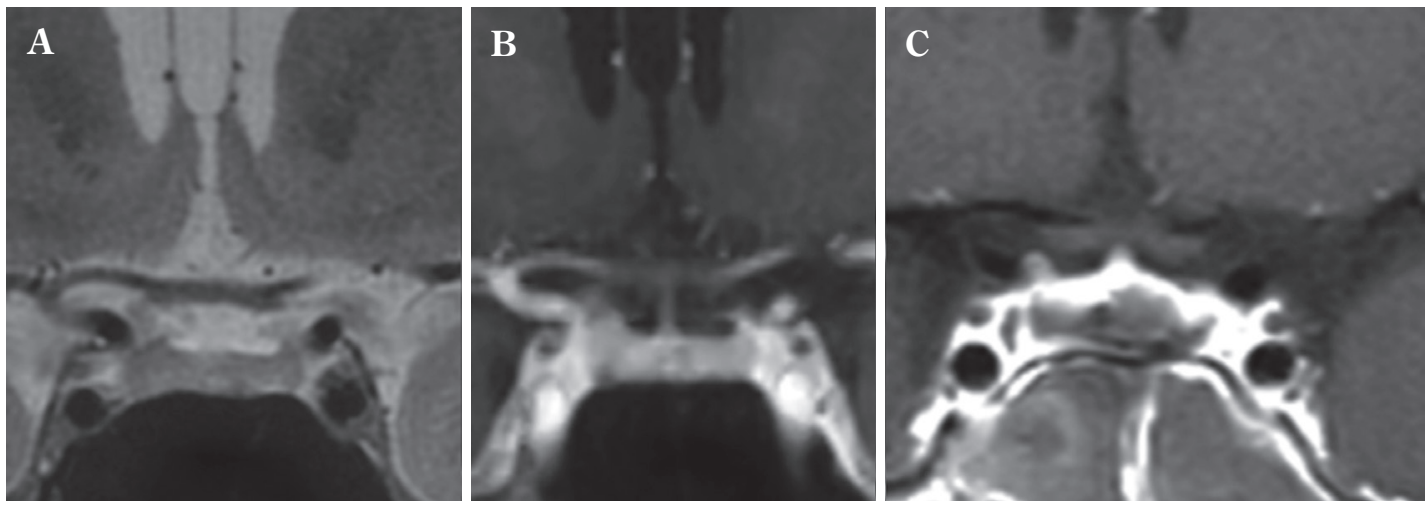

Fig. 2 Invisible tumor in a patient with Cushing's disease

Preoperative T2-weighted (A), gadolinium-enhanced T1-weighted (B), and postoperative enhanced T1 image (C) are shown. A small cystic lesion at the midline was Rathke's cleft cyst, which was detected during surgery. Although venous sampling showed an apparent left-side dominance of the ACTH gradient, the tumor was found at the right side of the pituitary gland. Endocrinological remission was obtained; however, we could not detect the tumor, even reviewing the preoperative MR images (A, B).

Table 2 Current available medical treatment for acromegaly in Japan (from Ref 21 and 24)

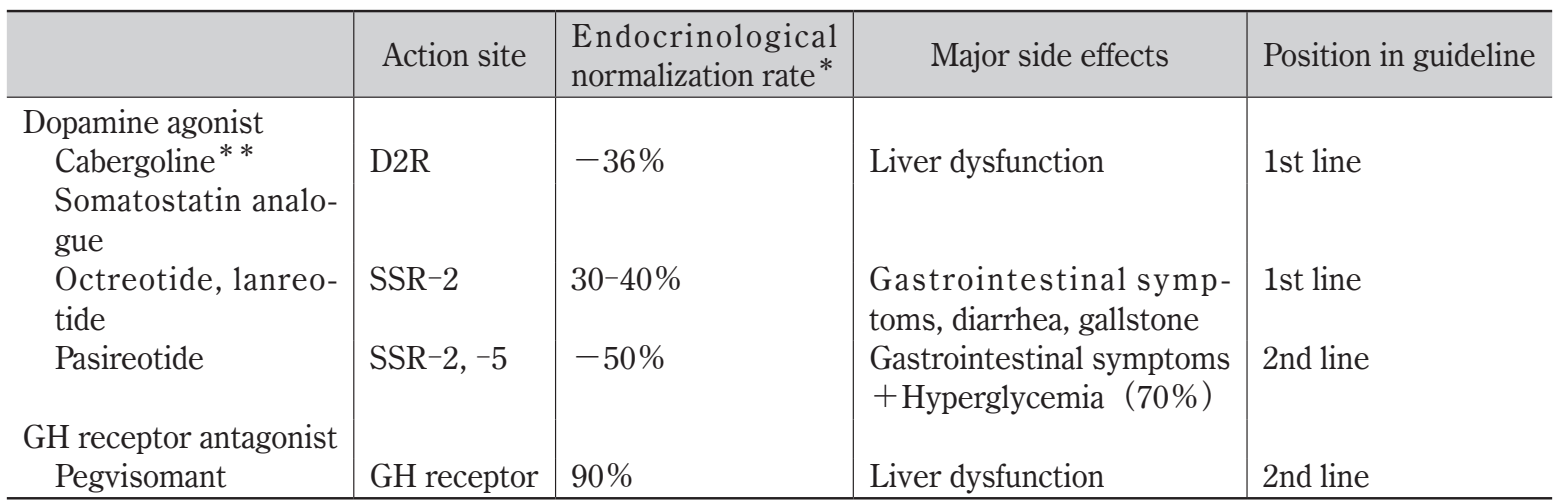

GH: growth hormone, D2R: dopamine receptor subtype 2, SSR-2 or 5: somatostatin receptor subtype 2 or 5

*The definitions of normalization : normal range of IGF-1+GH $<2.0$ (or 2.5) $\mathrm{ng} / \mathrm{ml}$

** Not approved by national health insurance

た例や高度な糖尿病合併例などへの投与が推奨されてい る。注意すべき副作用に肝機能障害がある。また投与中 は GH が高値となるため, 病勢の指標は IGF-1 のみとな

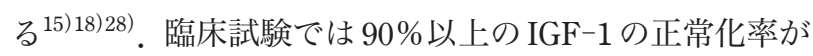
得られたが35)38), 実臨床では $60 \%$, 長期間の継続例で $78 \%$ だった ${ }^{4) 13)}$.この要因は投与量の違いで, 実臨床で は慎重に少量から投与される例が多かったためと推察さ れている ${ }^{23)}$. また作用機序からはクッシング病でみられ る Nelson 症候群のような現象が危惧されるが，2,090 例 を対象としたACROSTUDYでは腫瘍が増大したのは 6.8\%のみで pegvisomant の影響はなかったと判断されて いる4).ただし，投与中は MRIで残存腫瘍を定期的にモ ニタリングする必要はある ${ }^{18)}$.
実際は上記薬剤が併用されることが多く, 2019 年のド イツの報告では, 併用療法により 420 例中 $73 \%$ で IGF-1 が正常化し, 非正常化群の $57 \%$ IGF-1 が正常值の 1.25 倍以下にとどまっていたという31)。われわれの施設で 2011 年以降に経験した先端巨大症の薬物治療 34 例（才 クトレオチド 22 , ランレオチド 16 , パシレオチド 1 , ペ グビソマント 5 例, 重複あり) でも 31 例 (91\%) で IGF1 が正常化していた，放射線治療例を含むため正常化率 が高かったと考えられるが，実際ペグビソマントが投与 された 5 例では全例 IGF-1 が正常化し, 高い効果が確認 された。

先端巨大症に対する新規の薬剤として，オクトレオチ ドの内服薬や SSR-2 のアゴニスト, GH 受容体に対する 
Table 3 Current available medical treatment for Cushing disease in Japan (from Ref. 28, 29, 36)

\begin{tabular}{|c|c|c|c|c|}
\hline \multicolumn{2}{|c|}{ Action site } & $\begin{array}{l}\text { Endocrinological nor- } \\
\text { malization rate* }\end{array}$ & Major side effects & Position in guideline \\
\hline $\begin{array}{l}\text { Dopamine agonist } \\
\text { Cabergoline }\end{array}$ & $\mathrm{D} 2 \mathrm{R}$ & $\begin{array}{l}40 \rightarrow 5 \% \\
\text { (escape phenomenon) }\end{array}$ & Liver dysfunction & Adjuvant \\
\hline $\begin{array}{l}\text { Somatostatin analogu } \\
\text { Pasireotide }\end{array}$ & SSR $-2,-5$ & $-40 \%$ & $\begin{array}{l}\text { Gastrointestinal symptoms, } \\
\text { hyperglycemia }(70 \%)\end{array}$ & 1st line \\
\hline $\begin{array}{c}\text { Inhibitor of adrenal st } \\
\text { Metyrapone }\end{array}$ & $\begin{array}{l}\text { eroidogenesis } \\
11 \beta \text {-hydroxylase }\end{array}$ & $-43 \%$ & $\begin{array}{l}\text { Hypoadrenalism, liver dys- } \\
\text { function, androgeization }\end{array}$ & Adjuvant \\
\hline $\begin{array}{l}\text { Trilostane } \\
\text { Mitotane }\end{array}$ & $\begin{array}{l}3 \beta \text {-hydroxylase } \\
\text { CYP11A1,3A4 etc }\end{array}$ & $\begin{array}{l}\text { Rarely used } \\
72-82 \% \text { (add on cases) }\end{array}$ & $\begin{array}{l}\text { Hypoadrenalism } \\
\text { Permanent hypoadrenalism }\end{array}$ & $\begin{array}{l}\text { Rarely used } \\
\text { Rarely used }\end{array}$ \\
\hline
\end{tabular}

GH: growth hormone, D2R: dopamine receptor subtype 2 , SSR-2 or 5 : somatostatin receptor subtype 2 or 5

* The definitions of normalization: urine free cortisol< $<$ normal range

**Not approved by national health insurance

アンチセンス核酸医薬などが開発, 治験の段階であ る ${ }^{39)}$ 。またエストロゲンに GH 情報伝達系を抑制する作 用があるため, 選択的エストロゲン受容体調整薬の raloxifene や tamoxifen が男性や閉経後の女性の補助療法に 試みられている39).

\section{3 クッシング病の外科治療}

最近のメ夕解析のよると, クッシング病に対する手術 寬解率は，術後早期では $80 \%$ だが，一定数再燃し，5 年 後では $56 \%$ だった ${ }^{33}$. クッシング病に特徵的な問題点と して, 微小腺腫の約 $60 \%$ がMRI で描出されないことが 挙げられる ${ }^{27)}$. そのような場合, 現実的には静脈洞サン プリングでの左右差を参考に手術で腺腫を探索するが, 静脈還流などの問題もあり正答率は 56 ～66\% 程度と低 い27). 代表例を Fig. 2 に提示するが，同じように手術し ても寛解する例としない例があるのが実情である。われ われは微小腺腫の検出のために, より時間分解能の高い CTでの造影 dynamic 撮影を応用しているが, 他の機能 性下垂体腺腫と比べてクッシング病では正常下垂体と腺 腫の間に造影コントラストがつきにくい結果が得られて いる ${ }^{19)}$. 3 T の MRI で撮影法を工夫することで検出率が 上昇したという報告 ${ }^{14)}$ や methionine-PET, CRH 負荷下 の FDG-PET などの報告もあるが320), 海綿静脈洞壁に 浸潤するような微小腺腫をいかに描出できるかが，手術 成績向上に向けた今後の課題と考えられる.

\section{4 クッシング病の薬物治療}

クッシング病も外科治療で宽解に至らなかった例が薬
物治療の対象となるが, 著効例は少なく, 現実的には放 射線治療の役割が大きい ${ }^{39)}$ 。現在，クッシング病に使用 される薬物を Table 3 に示す，腫瘍に直接作用するもの として, ドパミン作動薬のカベルゴリン（保険承認外） と第二世代ソマトスタチン製剤のパシレオチドがある. カベルゴリンでは 30〜 40\%で尿中コルチゾール值の正 常化が得られるが，プロラクチノーマと比べて高用量を 要することが多く ${ }^{36)}$, 効果が徐々に減弱する escape 現象 がみられる例がある ${ }^{10)}$. またクッシング病に伴う精神症 状が強い例にも要注意である。パシレオチドは 2018 年 に保険承認された薬剤で, 尿中コルチゾール值の正常化 率は $40 \%$ だが22), 有効例では 3 年以上安定した効果が報 告されている ${ }^{11)}$. 重要な副作用として耐糖能の悪化があ り, 先端巨大症と同様，血糖管理には注意を要する ${ }^{34)}$.

クッシング病では, ACTHにより副腎皮質から分泌さ れるコルチゾールが実際に作用するで，その合成阻害薬 も治療に用いられる。コルチゾール合成阻害薬には，メ チラポン, ケトコナゾール (日本未承認), ミトタン, ト リロスタン 28 などがあるが，メチラポンが使用されるこ とが多い.メチラポンには即効性があるため, 手術前の 高コルチゾール血症の是正にも用いられる。メチラポン の投与法として，尿中コルチゾールが正常化するまで漸 増する方法と, 内因性のコルチゾールをしつかり抑制 し，必要な分をヒドロコルチゾンとして補充する方法 (block \& replacement) がある ${ }^{28)}$. 副作用には低血圧など 副腎不全様の症状や肝機能障害, フィードバックで ACTH の分泌が促進されることによる男性化（副腎での アンドロゲン合成が促進されるため) などがある ${ }^{28)}$ 。実 
臨床ではパシレオチドとメチラポンを組み合わせて用い られることも多い.

また病勢が激しく生命の危険がある場合には両側の副 腎摘出も 1 つの選択となるが27), その場合, Nelson 症候 群になる恐れがある, 従来は, あらかじめ残存腫瘍に放 射線治療が追加されていたが, 最近はパシレオチドが使 用されている812).

クッシング病に対する開発もしくは治験中の薬剤に は，まず腫瘍を標的とした roscovitine (cylclin-dependent kinase 2 の阻害薬) や gefitinib (epidermal growth factor receptor 阻害薬) などの分子標的薬や corticotroph の増殖 や ACTH 分泌を抑制するビタミン A 由来のレチノイン 酸, 腫瘍細胞に過剰に発現している heat shock protein 90 を抑制する silibinin などがある $\left.{ }^{34)} 39\right)$ 。また副腎皮質での コルチゾール合成経路の阻害剤としては levoketoconazole, ATR-101 や osilodrostat が，グルココルチコイ ド受容体拮抗剤としては mifepristone〔米国食品医薬品 局（FDA）では認可済み]や治験中の relacorilant などが ある ${ }^{34) 39)}$.

\section{まとめ}

機能性下垂体腺腫に対して, 従来のドパミン作動薬と ソマトスタチン製剤に加え, 分子標的薬などさまざまな 薬剤が開発中であるが，その効果は腫瘍細胞に発現する 受容体や遺伝子によって異なる。今後はWHO の新分類 の普及に加え, 受容体や遺伝子の情報が蓄積されること で，個々の腫瘍の特性に合わせた治療法が選択できる時 代になると推測される。しかし, 疾患の本態が良性のホ ルモン産生腫瘍であるかぎり, 治療の主軸はやはり手術 による摘出と考えられる。患者の状態に合わせた安全か つ効果的な外科治療を提供することが，今後の脳神経外 科の重要な役割と考えられる。

著者全員は日本脳神経外科学会への COI 自己申告の登録を 完了しています。本論文に関して開示すべき COI はありませ h.

\section{文 献}

1) Bolfi F, Neves AF, Boguszewski CL, Nunes-Nogueira VS : Mortality in acromegaly decreased in the last decade : a systematic review and meta-analysis. Eur J Endocrinol 179 : 59-71, 2018

2) Bonert V : Do nothing but observe microprolactinomas : when and how to replace sex hormones? Pituitary 23 : 307-313, 2020

3) Boyle J, Patronas NJ, Smirniotopoulos J, Herscovitch P,
Dieckman W, Millo C, Maric D, Chatain GP, Hayes CP, Benzo S, Scott G, Edwards N, Ray Chaudhury A, Lodish MB, Sharma S, Nieman LK, Stratakis CA, Lonser RR, Chittiboina $\mathrm{P}$ : CRH stimulation improves 18 F-FDG-PET detection of pituitary adenomas in Cushing's disease. Endocrine 65: 155-165, 2019

4) Buchfelder M, van der Lely AJ, Biller BMK, Webb SM, Brue T, Strasburger CJ, Ghigo E, Camacho-Hubner C, Pan K, Lavenberg J, Jönsson P, Hey-Hadavi JH : Long-term treatment with pegvisomant: observations from 2090 acromegaly patients in ACROSTUDY. Eur J Endocrinol 179: 419427, 2018

5) Caputo C, Prior D, Inder WJ : The need for annual echocardiography to detect cabergoline-associated valvulopathy in patients with prolactinoma : a systematic review and additional clinical data. Lancet Diabetes Endocrinol 3 : 906-913, 2015

6) Casanueva FF, Molitch ME, Schlechte JA, Abs R, Bonert V, Bronstein MD, Brue T, Cappabianca P, Colao A, Fahlbusch R, Fideleff H, Hadani M, Kelly P, Kleinberg D, Laws E, Marek J, Scanlon M, Sobrinho LG, Wass JA, Giustina A : Guidelines of the Pituitary Society for the diagnosis and management of prolactinomas. Clin Endocrinol (Oxf) 65 : 265-273, 2006

7) Coopmans EC, Muhammad A, van der Lely AJ, Janssen JAMJ, Neggers SJCM : How to position pasireotide LAR treatment in acromegaly. J Clin Endocrinol Metab 104: 1978-1988, 2019

8) Daniel E, Debono M, Caunt S, Girio-Fragkoulakis C, Walters SJ, Akker SA, Grossman AB, Trainer PJ, Newell-Price J : A prospective longitudinal study of pasireotide in Nelson's syndrome. Pituitary 21:247-255, 2018

9) Even-Zohar N, Greenman $Y$ : Management of NFAs : medical treatment. Pituitary 21: 168-175, 2018

10) Ferriere $A$, Cortet $C$, Chanson P, Delemer B, Caron P, Chabre O, Reznik Y, Bertherat J, Rohmer V, Briet C, Raingeard I, Castinetti F, Beckers A, Vroonen L, Maiter D, CephiseVelayoudom FL, Nunes ML, Haissaguerre M, Tabarin A : Cabergoline for Cushing's disease: a large retrospective multicenter study. Eur J Endocrinol 176 : 305-314, 2017

11) Fleseriu M, Petersenn S, Biller BMK, Kadioglu P, De Block C, T'Sjoen G, Vantyghem MC, Tauchmanova L, Wojna J, Roughton M, Lacroix A, Newell-Price J : Long-term efficacy and safety of once-monthly pasireotide in Cushing's disease : A Phase III extension study. Clin Endocrinol (Oxf) 91: 776-785, 2019

12) Fountas A, Lim ES, Drake WM, Powlson AS, Gurnell M, Martin NM, Seejore K, Murray RD, MacFarlane J, Ahluwalia R, Swords F, Ashraf M, Pal A, Chong Z, Freel M, Balafshan T, Purewal TS, Speak RG, Newell-Price J, Higham CE, Hussein Z, Baldeweg SE, Dales J, Reddy N, Levy MJ, Karavitaki $\mathrm{N}$ : Outcomes of patients with Nelson's syndrome after primary treatment: A multicenter study from $13 \mathrm{UK}$ pituitary centers. J Clin Endocrinol Metab 105: dgz200, 2020

13) Freda PU, Gordon MB, Kelepouris N, Jonsson P, KoltowskaHaggstrom M, van der Lely AJ : Long-term treatment with pegvisomant as monotherapy in patients with acromegaly: experience from ACROSTUDY. Endocr Pract 21:264274,2015

14) Fukuhara N, Inoshita N, Yamaguchi-Okada $M$, Tatsushima K, Takeshita A, Ito J, Takeuchi Y, Yamada S, Nishioka H : 
Outcomes of three-Tesla magnetic resonance imaging for the identification of pituitary adenoma in patients with Cushing's disease. Endocr J 66:259-264, 2019

15) Giustina A, Ambrosio MR, Beck Peccoz P, Bogazzi F, Cannavo' S, De Marinis L, De Menis E, Grottoli S, Pivonello $\mathrm{R}$ : Use of pegvisomant in acromegaly. An Italian Society of Endocrinology guideline. J Endocrinol Invest $\quad 37$ : 10171030, 2014

16) Hattori $N$, Ishihara $T$, Saiki $Y$ : Macroprolactinaemia : prevalence and aetiologies in a large group of hospital workers. Clin Endocrinol (Oxf) 71:702-708, 2009

17) Kasuki L, da Silva Rocha P, Lamback EB, Gadelha MR: Determinants of morbidities and mortality in acromegaly. Arch Endocrinol Metab 63 : 630-637, 2019

18) Katznelson L, Laws ER Jr, Melmed S, Molitch ME, Murad MH, Utz A, Wass JA ; Endocrine Society: Acromegaly : an Endocrine Society clinical practice guideline. J Clin Endocrinol Metab 99: 3933-3951, 2014

19) Kinoshita M, Tanaka H, Arita H, Goto $Y$, Oshino S, Watanabe Y, Yoshimine T, Saitoh Y : Pituitary-targeted dynamic contrast-enhanced multisection CT for detecting MR imagingoccult functional pituitary microadenoma. AJNR Am J Neuroradiol 36:904-908, 2015

20) Koulouri O, Steuwe A, Gillett D, Hoole AC, Powlson AS, Donnelly NA, Burnet NG, Antoun NM, Cheow H, Mannion RJ, Pickard JD, Gurnell M : A role for 11C-methionine PET imaging in ACTH-dependent Cushing's syndrome. Eur J Endocrinol 173: M107-120, 2015

21) Kyriakakis N, Seejore K, Hanafy A, Murray RD : Management of persistent acromegaly following primary therapy:

The current landscape in the UK. Endocrinol Diabetes Metab 3: e00158, 2020

22) Lacroix A, Gu F, Gallardo W, Pivonello R, Yu Y, Witek P, Boscaro M, Salvatori R, Yamada M, Tauchmanova L, Roughton M, Ravichandran S, Petersenn S, Biller BMK, Newell-Price $\mathrm{J}$; Pasireotide G2304 Study Group : Efficacy and safety of once-monthly pasireotide in Cushing's disease : a 12 month clinical trial. Lancet Diabetes Endocrinol $\quad 6: 17-26,2018$

23) Melmed S, Bronstein MD, Chanson P, Klibanski A, Casanueva FF, Wass JAH, Strasburger CJ, Luger A, Clemmons DR, Giustina A : A consensus statement on acromegaly therapeutic outcomes. Nat Rev Endocrinol 14:552-561, 2018

24) Melmed S, Casanueva FF, Hoffman AR, Kleinberg DL, Montori VM, Schlechte JA, Wass JA ; Endocrine Society : Diagnosis and treatment of hyperprolactinemia : an Endocrine Society clinical practice guideline. J Clin Endocrinol Metab 96:273-288, 2011

25) Molitch ME : Diagnosis and treatment of pituitary adenomas: A review. JAMA 317:516-524, 2017

26) Molitch ME : Endocrinology in pregnancy: management of the pregnant patient with a prolactinoma. Eur J Endocrinol 172: R205-213, 2015

27) Nieman LK, Biller BM, Findling JW, Murad MH, NewellPrice J, Savage MO, Tabarin A ; Endocrine Society: Treatment of Cushing's syndrome : An Endocrine Society clinical practice guideline. J Clin Endocrinol Metab 100:28072831, 2015

28）厚生労働科学研究費補助金難治性疾患等政策研究事業 「間脳下垂体機能障害に関する調査研究」班, 日本内分泌 学会編：間脳下垂体機能障害の診断と治療の手引き (平 成 30 年度改訂). 日内分泌会誌 95 (suppl) : 1-14, 2019.

29）西岡 宏，井下尚子：下垂体腫瘍の 2017 年 WHO 組織分
類. No Shinkei Geka 47:597-606, 2019

30) Osamura RY, Grossman A, Korbonits M, Kovacs K, Lopes MBS, Matsuno A, Trouillas J : Pituitary adenoma. in Lloyd RV, Osamura RY, Klöppel RJ (eds) : WHO Classification of Tumours of Endocrine Organs, 4th ed. Lyon, IARC, 2017, pp.11-63.

31) Quinkler M, Petroff D, Knappe UJ, Schopohl J, Tönjes A, Schmid SM : Medical therapy of acromegaly in Germany 2019 - Data from the German acromegaly registry. Exp Clin Endocrinol Diabetes 2020 [Online ahead of print]

32) Souteiro P, Karavitaki N : Dopamine agonist resistant prolactinomas: any alternative medical treatment? Pituitary $23: 27-37,2020$

33) Stroud A, Dhaliwal P, Alvarado R, Winder MJ, Jonker BP, Grayson JW, Hamizan A, Harvey RJ, McCormack A : Outcomes of pituitary surgery for Cushing's disease : a systematic review and meta-analysis. Pituitary 23:595-609, 2020

34) Theodoropoulou M, Reincke M : Tumor-directed therapeutic targets in Cushing disease. J Clin Endocrinol Metab 104: 925-933, 2019

35) Trainer PJ, Drake WM, Katznelson L, Freda PU, HermanBonert V, van der Lely AJ, Dimaraki EV, Stewart PM, Friend KE, Vance ML, Besser GM, Scarlett JA, Thorner MO, Parkinson C, Klibanski A, Powell JS, Barkan AL, Sheppard MC, Malsonado M, Rose DR, Clemmons DR, Johannsson G, Bengtsson BA, Stavrou S, Kleinberg DL, Cook DM, Phillips LS, Bidlingmaier M, Strasburger CJ, Hackett S, Zib K, Bennett WF, Davis RJ: Treatment of acromegaly with the growth hormone-receptor antagonist pegvisomant. $N$ Engl J Med 342: 1171-1177, 2000

36) Tritos NA, Biller BMK : Current management of Cushing's disease. J Intern Med 286 : 526-541, 2019

37) Trouillas J, Jaffrain-Rea ML, Vasiljevic A, Raverot G, Roncaroli F, Villa C: How to classify the pituitary neuroendocrine tumors (PitNET) s in 2020. Cancers (Basel) $12: 514,2020$

38) van der Lely AJ, Hutson RK, Trainer PJ, Besser GM, Barkan AL, Katznelson L, Klibanski A, Herman-Bonert V, Melmed S, Vance ML, Freda PU, Stewart PM, Friend KE, Clemmons DR, Johannsson G, Stavrou S, Cook DM, Phillips LS, Strasburger CJ, Hackett S, Zib KA, Davis RJ, Scarlett JA, Thorner MO : Long-term treatment of acromegaly with pegvisomant, a growth hormone receptor antagonist. Lancet 358: 1754-1759, 2001

39) Varlamov EV, McCartney S, Fleseriu M : Functioning pituitary adenomas - Current treatment options and emerging medical therapies. Eur Endocrinol 15: 30-40, 2019

40) Vilar L, Abucham J, Albuquerque JL, Araujo LA, Azevedo MF, Boguszewski CL, Casulari LA, Cunha Neto MBC, Czepielewski MA, Duarte FHG, Faria MDS, Gadelha MR, Garmes HM, Glezer A, Gurgel MH, Jallad RS, Martins M, Miranda PAC, Montenegro RM, Musolino NRC, Naves LA, Ribeiro-Oliveira Júnior A, Silva CMS, Viecceli C, Bronstein $\mathrm{MD}$ : Controversial issues in the management of hyperprolactinemia and prolactinomas - An overview by the Neuroendocrinology Department of the Brazilian Society of Endocrinology and Metabolism. Arch Endocrinol Metab 62 : 236-263, 2018

41) Vilar L, Vilar CF, Lyra R, Freitas MDC : Pitfalls in the diagnostic evaluation of hyperprolactinemia. Neuroendocrinology 109: 7-19, 2019

42) Wang M, Mou C, Jiang M, Han L, Fan S, Huan C, Qu X, Han 
T, Qu Y, Xu G: The characteristics of acromegalic patients with hyperprolactinemia and the differences in patients with merely $\mathrm{GH}^{-}$secreting adenomas : clinical analysis of 279 cases. Eur J Endocrinol $\quad$ 166 : 797-802, 2012
43) Zanettini R, Antonini A, Gatto G, Gentile R, Tesei S, Pezzoli $\mathrm{G}$ : Valvular heart disease and the use of dopamine agonists for Parkinson's disease. N Engl J Med 356:39-46, 2007

要

機能性下垂体腺腫の薬物治療と手術適応

押野 悟 齋藤洋一 木下 学 貴島 晴彦

機能性下垂体腺腫のうち, プロラクチノーマはドパミン作動薬による薬物治療が第一選択となる が, その診断にはいくつかの注意点がある. 治療目標は患者の状況によって異なるが, 長期間 PRL 值 の制御が必要な若年女性のマク口腺腫例には, 総合的に外科治療の意義があると考える. 先端巨大症 とクッシング病に対しては外科治療が第一選択で, 非寬解例に薬物治療が適用される. 腫瘍を標的と したドパミン作動薬とソマトスタチン誘導体が治療の主軸で, GH 受容体拮抗剤やコルチゾール合成 阻害剤が補助的に使用される. それらの組み合わせで先端巨大症では内分泌学的に制御される例が増 加したのに対し, クッシング病ではまだ薬物治療の効果は不十分である. さまざまな薬物が開発中で あるが，機能性下垂体腺腫に対しては手術での摘出が理想的である. 全摘出できない例でも最大限に 腫瘍を摘出し, 受容体や遺伝子の性状から有効な補助療法を選択するのが今後の方向性となるだろう. 